only a small proportion of our beef from pure beef herds ; the bulk of our beef must be obtained from dual-purpose cattle or from these crossed with a beef bull. To obviate the danger that heifers from this cross may find their way into dairy herds and so reduce the efficiency of the dairy industry, he advised the use of beef bulls having a distinctive colour marking, such as the Hereford (white face) or Aberdeen Angus (black colour), which are dominant genetic characters and so colour-mark their offspring with a trade mark for beef.

A plan for the organization of machinery instruction within the county education framework was outlined by Mr. D. I. MeLaren, who contended that the facilities available for obtaining advice on agricultural engineering problems have not kept pace with those provided for the other branches of the industry. Among other recommendations he suggested the inauguration of an advisory service, partly within the county under the charge of a suitably trained man with the status of assistant county agricultural organizer, and partly on a provincial basis, with an adviser in agricultural engineering on the lines of the existing advisers in chemistry, economics, etc.

Mr. C. Davies put in a plea for the reduction of types and varieties of farm machines on the grounds that many of them are not really necessary. He said that the War has taught us to do without many things in ordinary life which were previously considered necessities, and many tools which formerly were considered useless unless of a very exact shape are unobtainable to-day; but we shall find that other shapes do just as well and sometimes even better. In the case of the plough, of which very many types exist, he said that the demands for a particular shape or type are often due, not to a profound knowledge of what the soil requires, but to local custom or prejudice. The same holds good for other farm implements and machinery. Mr. Davies said that it is not in the farmer's own interest to ask for an unnecessary variety of implements, because the fewer the number of different shapes and types a manufacturer has to turn out the lower the costs, and the lower the charge to the farmer. The farmer of the future will have to be more machine-minded, remarked Mr. Davies ; no factory can afford to abuse the mechanical equipment it has installed to the same extent as happens on so many farms, and continue to pay dividends. In the discussion on this paper, it was pointed out that the farmer is not entirely to blame in failing to protect his machinery from the weather; the great shortage of suitable farm buildings puts him in a very difficult position, especially now that new construction is limited because of shortage of materials.

\section{IMPROVEMENT OF LIVESTOCK}

DROF. ROBERT RAE, of the University of Reading, contributed a valuable address on the improve. ment of livestock to the proceedings of the National Veterinary Medical Association of Great Britain and Ireland (Vet. Rec., 55, 429; 1943).

During the War, he said, millions of acres of land have been ploughed up and there have been tremendous increases in crops which can be consumed directly, such as potatoes, barley, wheat, sugar beet and so on. Before the War Great Britain imported ten million tons or so of feeding stuffs for farm animals at a cost of about fifty million pounds a year. Producers of pigs, poultry and milk were most dependent on this, sheep farmers were least so. As the War decreased the shipping available for these imports, first priority in imported foodstuffs was given to dairy cows and milk production, while pigs and poultry came last, because they are almost entirely dependent on the concentrated foods which are largely imported. At the present moment the numbers of our dairy cows have been maintained, with a small increase, but beef cattle and sheep have been reduced to some extent. At the same tirne our large livestock population has built up reserves of soil fertility which has helped our crop production.

Prof. Rae thinks that livestock production must remain after the War the predominant feature of British agriculture. We shall need fresh (perishable) agricultural products ; large areas of Great Britain are not suitable for intensive arable cultivation, although much of this land can be improved; even in our arable areas there is much land which cannot without the fertilizing power of livestock upon it be kept in what the farmer so graphically and beautifully calls 'good heart'. Prof. Rae does not advocate the return of large areas to permanent grass. He thinks that the war-time policy of temporary pastures, endorsed by generations of Scottish farming, should be continued after the War. They give fresh, clean pastures and should give increased stock-carrying capacity and the opportunity of using the fertility accumulated by the livestock. This system of temporary leys has been introduced by the County War Agricultural Committees much more quickly than it could have been introduced in normal times.

Prof. Rae thinks, however, that we do not produce enough food for even our pre-war numbers of livestock. We ought to revert to our pre-War numbers of livestock or to increase them, and, if we do, we shall need imported foods again after the War. Further, Great Britain has often been called the stud farm of the world. The best herds and flocks of many other countries, of theDominions Overseas and of North and South America were founded on stock supplied by Great Britain, and our pre-War trade in breeding stock was valuable. We could, indeed, be proud of our breeding stock; but we could not be satisfied with a good deal of our ordinary stock in the fields. The level of all livestock in Great Britain needs to be raised; more farmers should attempt the difficult job of breeding. More breeders and fewer mere multipliers of stock is, in Prof. Rae's opinion, a sound maxim for the future.

The rest of his address develops this theme by interesting and valuable summary and comment upon some of the schemes which seek, at present, to improve dairy cattle and pigs in Great Britain. How many people, one wonders, when they get their loaves and bacon and bottles of milk, are aware of the vast organization, the immense labours of mind and muscle and the complex organization and machinery which combine to deliver them at their doors? More than one book has been written about the marvellous organization which delivers at our doors the daily newspaper; and marvellous that organization is : but how much greater, how beneficent and how poorly appreciated are the miracles daily done on the English farm.

Among contributors to the instructive discussion which followed this address were Colonel E. M. Curley, chief veterinarian, European Theatre of Operations, United States Army, and Dr. Tj. Bakker, who gave interesting accounts of some aspects of veterinary work in the United States and Holland. 